\title{
ANALISIS PERSEPSI PETERNAK AYAM BROILER TERHADAP KEMITRAAN DAN FAKTOR - FAKTOR YANG MEMPENGARUHINYA
}

\author{
O. Emrananda ${ }^{1 \text { a }}$, I. Novita ${ }^{1}$ dan S. Masithoh ${ }^{1}$ \\ ${ }^{1}$ Jurusan Agribisnis, Fakultas Pertanian Universitas Djuanda Bogor \\ Jalan Tol Ciawi No. 1 Kotak Pos 35 Bogor 16720 \\ ${ }^{a}$ Korespondensi: Ori Emrananda, Email: Ori.emrananda@unida.ac.id
}

\begin{abstract}
ABSTRAK
Peternakan merupakan salah satu subsektor pertanian yang berperan mendorong pertumbuhan perekonomian di Indonesia. Subsektor peternakan berkontribusi dalam menyediakan kebutuhan daging nasional dan meningkatkan status gizi masyarakat juga banyak menyerap tenaga kerja secara signitifikan. Penelitian ini dilakukan di Kecamatan Leuwiliang Kabupaten Bogor. Tujuan penelitian ini untuk mengetahui keragaan kemitraan, persepsi peternak dan faktor - faktor yang mempengaruhi persepsi peternak. Metode pengumpulan data meliputi data primer (observasi lapangan dan wawancara dengan kuesioner) dan data sekunder (studi literatur). Hasil penelitian menunjukkan 1) Peternak mandiri memberikan persepsi dengan cukup terhadap kemitraan dengan nilai rataan skor 61,5. Peternak Mitra memberikan persepsi cukup terhadap kemitraan dengan nilai rataan skor sebesar 69,48, 2) faktor-faktor yang mempengaruhi persepsi peternak ayam broiler terhadap kemitraan di kecamatan Leuwiliang Kabupaten Bogor yaitu faktor jumlah ternak dengan nilai nilai signifikansi sebesar 0,015, karena nilai signifikansi $<0,2(0,015<0.2)$ dan pengalaman ternak dengan nilai signifikansi sebesar 0,114, karena nilai signifikansi $<0,2(0,114<0,2)$.
\end{abstract}

Kata Kunci: Persepsi, Kemitraan. Ayam Broiler

\section{PENDAHULUAN}

Peternakan merupakan salah satu subsektor pertanian yang berperan mendorong pertumbuhan perekonomian di Indonesia. Subsektor peternakan berkontribusi dalam menyediakan kebutuhan daging nasional dan meningkatkan status gizi masyarakat juga banyak menyerap tenaga kerja secara signitifikan (Rohim, 2017). Menurut data BPS (2017) konsumsi daging di Indonesia didominasi oleh daging sapi kerbau serta daging ayam.

Pada tahun 2016 produksi daging nasional mencapai 3350 ton cenderung terus meningkat dari tahun-tahun sebelumnya tetapi pada tahun 2017 mengalami penurunan menjadi 3300 ton (Badan Pusat Statistik, 2017). Fenomena ini tidak sesuai dengan permintaan konsumsi rata-rata daging yang semakin tahun semakin meningkat.Hal ini berhubungan dengan tingkat kebutuhan konsumen seperti : konsumen rumah tangga, Industri Besar Sedang (IBS), Industri Mikro Kecil (IMK), Hotel, Restoran, Katering (Horeka) serta penyedia makan minum lainnya.

Provinsi Jawa Barat merupakan salah satu provinsi yang memproduksi daging ayam broiler terbesar di Indonesa, produksi tersebut hampir tersebar di seluruh kabupaten yang ada di Jawa Barat. Berdasarkan Data Badan Pusat Statistik Jawa Barat 2018, Kabupaten Bogor pada tahun 2016 menjadi salah satu sentra produksi daging ayam Broiler yaitu sebesar 87.934.335 ton setelah Kabupaten Ciamis dengan produksi sebesar 114.886.666 ton. Kabupaten Bogor memiliki beberapa kecamatan, salah satu sentra produksi ayam broiler di Kabupaten 
Bogor adalah Kecamatan leuwiliang dengan produksi pada tahun 2017 sebesar $1.515 .726 \mathrm{~kg}$.

Peternak ayam broiler yang ada di Kecamatan Leuwiliang memiliki sistem beternak secara mandiri dan secara kemitraan. Kebanyakan peternak tersebut lebih memilih melakukan beternak secara kemitraan, hal ini dikarenakan memiliki potensi yang cukup menjanjikan untuk pengembangan usaha peternakan ayam broiler, selain itu juga didukung oleh topografi dan luas lahan yang memadai. Namun adanya asumsi peternak terhadap tingginya harga pakan saat melakukan sistem kontrak tidak sesuai dengan keadaan di pasaran dan tidak sebanding dengan harga jual yang diberikan perusahaan mitra, adanya tempo yang cukup lama dalam pembayaran hasil produksi peternak, tidak sesuainya pakan yang diberikan oleh perusahaan mitra dengan target bobot ayam yang ditetapkan perusahaan mitra dalam hal ini kualitas pakan yang kurang baik, serta adanya anggapan peternak bahwasanya proses bermitra sangat sulit melihat adanya persyaratan tertentu.

Konsep kemitraan merupakan pola usaha yang sudah lama dikenal dan diharapkan dapat menjadi salah satu motivasi untuk merangsang tumbuhnya agribinis peternakan ayam broiler terutama mengatasi ketimpangan ekonomi usaha skala kecil-menengah dengan usaha skala besar (Pramita dkk, 2017).

Menurut Purbata dkk (2015) motivasi kemitraan antara pelaku dapat dipengaruhi oleh tujuan masing-masing, sebagai pendorong internal dan faktorfaktor yang berasal dari eksternal yang dihadapi oleh pelaku kemitraan mendapat nilai yang berbeda. Hal ini mengindikasikan kemitraan yang telah dijalankan belum memberi manfaat sepenuhnya kepada kedua belah pihak.

Penelitian ini bertujuan untuk mengetahui keragaan kemitraan peternak ayam broiler, menganalisis tingkat persepsi peternak ayam broiler terhadap kemitraan dan mengetahui faktor - faktor yang mempengaruhi persepsi peternak ayam broiler terhadap kemitraan di kecamatan Leuwiliang Kabupaten Bogor

\section{BAHAN DAN METODE}

\section{Lokasi dan waktu Penelitian}

Penelitian ini dilaksanakan di Kecamatan Leuwiliang, Kabupaten Bogor, Provinsi Jawa Barat. Pemilihan lokasi penelitian dilakukan secara sengaja (purposive) dengan pertimbangan bahwa kecamatan Leuwiliang yang menjadi sentra produksi ayam broiler di Kabupaten Bogor. Penelitian ini dilakukan dari bulan Agustus 2018 sampai dengan September 2018.

\section{Jenis dan Sumber Data}

Data yang digunakan pada penelitian ini adalah data primer dan data sekunder. Data primer diperoleh dari hasil wawancara responden dan melalui pengisian kuisioner yang telah disiapkan. Data sekunder diperoleh dari instansi terkait meliputi Departemen Pertanian Kementrian Pertanian, Badan Pusat Statistik, jurnal ilmiah, penelitianpenelitian terdahulu dan literatur pendukung baik melalui buku maupun internet.

\section{Metode pengambilan sample dan pengumpulan data}

Penelitian ini menggunakan metode sampling jenuh yaitu merupakan teknik penentuan sampel dengan cara mengambil seluruh populasi peternak ayam broiler di Kecamatan Leuwiliang yang berjumlah 33 orang peternak (Pusat Kesehatan Hewan Wikayah II, 2018). Pengumpulan data dilakukan dengan wawancara menggunakan daftar pertanyaan dan pengisian kuisioner yang telah disiapkan.

\section{Analisis data}

Data yang diolah dan dianalisis dalam penelitian ini adalah data kualitatif dan kuantitatif. proses pengolahan data kuantitatif didukung oleh program SPSS 
versi 22.0 for windows dan Microsoft Excel. Analisis data menggunakan dua analisis yaitu analisis deskriptif dan analisis Korelasi Rank Spearman. analisis deskriftif untuk mengetahui gambaran keadaan lokasi penelitian dan karakteristik peternak mandiri atau plasma dan persepsi peternak terhadap kemitraan.

1. Analisis korelasi Rank Spearman digunakan untuk mengetahui ada atau tidaknya hubungan antara karakteristik peternak dengan persepsi peternak terhadap pelaksanaan kemitraan. Karakteristik peternak yang akan dianalisis menggunakan Rank Spearman adalah umur, pengalaman beternak, jumlah ternak, tanggungan keluarga, pendapatan.

Rumus Rank Spearman $=1-\frac{6 \sum_{i=1}^{N} d_{i}^{2}}{N^{3}-N}$ Keterangan :

$\mathrm{r}_{\mathrm{s}}=$ Nilai koefisien korelasi

$\mathrm{d}_{\mathrm{i}}=$ Selisih nilai peringkat ke $\mathrm{i}$ antara variabel karakteristik peternak dengan variabel tingkat motivasi

$N=$ Jumlah sampel peternak

Dimana :

$\mathrm{X} 1$ : umur (tahun)

$\mathrm{X} 2$ : pengalaman beternak (tahun)

$\mathrm{X} 3$ : jumlah ternak (ekor)

$\mathrm{X} 4$ : tanggungan keluarga (orang)

$\mathrm{X} 5$ : pendapatan (Rp/bulan)

Dan persepsi peternak diukur berdasarkan Y :
a. Prosedur bermitra
b. Pelayanan teknis
c. Pelayanan sarana produksi
d. Pelayanan pasca panen

2. Analisis deskriptif

Analisis deskriptif untuk mengetahui gambaran keadaan lokasi penelitian dan karakteristik peternak terhadap kemitraan

3. Skala Likert

Skala Likert digunakan untuk mengukur sikap, pendapat dan persepsi seseorang tentang fenomena sosial (Sugiyono, 2016). 1-4 untuk mengukur persepsi peternak. Tingkat pemberian skor

a. skor 4 untuk jawaban sangat penting

b. skor 3 untuk jawaban penting c. skor 2 untuk jawaban tidak penting

d. skor 1 untuk jawaban sangat tidak penting

\section{HASIL DAN PEMBAHASAN}

\section{Karakteristik Peternak Ayam Broiler di Kecamatan Leuwiliang Kabupaten Bogor}

Karakteristik peternak sebagian besar peternak berumur kategori muda antara 23-44 tahun, sebanyak $(69,7 \%)$, berjenis kelamin laki-laki, memiliki pengalaman beternak kategori pemula $(57,6 \%)$ lebih dari setengah peternak $(72,7 \%)$ memiliki ternak pada kategori sedikit, lebih dari sebagian peternak memiliki tanggungan keluarga sedikit $(60,6 \%)$ dan sebagian besar $(48,5 \%)$ peternak berpendapatan antara 1.000.0003.500.000 dalam usaha ternaknya.

Pola kemitraan yang ada di Kecamatan Leuwiliang ada 2 diantaranya Pola Inti Plasma dan Kerjasama Operasional. Keragaan kemitraan Peternak ayam broiler di Kecamatan Leuwiliang Kabupaten Bogor didapatkan bahwa mayoritas status peternak yaitu bermitra. Data keragaan kemitraan peternak ayam broiler Kecamatan Leuwiliang Kabupaten Bogor yaitu BNF (Berkah Nyawiji Farm), TJB (Taman Jasmin Bogor), PT. BBM (Berkah Broiler Mandiri), SMSS (Satwa Maju Sejahtera Sempurna), MKF (Manik Kembar Farm), TPC (Tri Putra Cerdas), MMF (Makmur Mulyo Family), $\mathrm{H}$. Mukhlis, GK Farm Cibinong, New Hope, MMS dan Mandiri.

\section{Hak dan Kewajiban Pola Kemitraan}

1. Pola Inti Plasma

Pola inti plasma merupakan hubungan kemitraan antara kelompok mitra dengan perusahaan mitra dimana perusahaan mitra bertindak sebagai inti dan kelompok mitra bertindak sebagai plasma. Dalam pola ini perusahaan inti berkewajiban memberi bimbingan atau pembinaan dalam teknologi, penyedia 
dalam hal penyedia sarana produksi mulai dari penyediaan DOC, pakan, vaksin, obatobatan, vitamin. Pemberian bimbingan teknis, dan sampai pada penyediaan pemasaran hasil. Peternak plasma wajib menjual hasil produksinya pada perusahaan inti dan memenuhi aturan yang diberikan perusahaan inti. Selain itu kewajiban yang harus dilakukan peternak yaitu melakukan budidaya dengan baik dan memenuhi kebutuhan atau permintaan perusahaan inti sesuai yang telah disepakati.

2. Pola Kerjasama Operasional

Pola kerjasama operasional merupakan hubungan antara kelompok mitra dengan perusahaan mitra dimana kelompok mitra menyediakan lahan, sarana dan tenaga kerja sedangkan perusahaan menyediakan modal serta sarana untuk budidaya, sementara untuk pembagian hasil sesuai kesepakatan awal. Pola kerjasama operasional biasanya tidak menggunakan perjanjian secara tertulis. Saat berlangsungnya pemeliharaan, pihak perusahaan tidak melakukan bimbingan budidaya kepada peternak dan kerugian ditanggung oleh peternak.

Keunggulan kemitraan pola inti plasma ini adalah dapat memberi manfaat timbal balik antara perusahaan inti dan peternak plasma melalui cara pemberian bimbingan dalam proses budidaya dan penyediaan hasil panen yang terjamin.

Data keragaan kemitraan peternak ayam broiler Kecamatan Leuwiliang Kabupaten Bogor sebagai berikut:

1. BNF (Berkah Nyawiji Farm)

2. TJB (Taman Jasmin Bogor)

3. PT. BBM (Berkah Broiler Mandiri)

4. SMSS (Satwa Maju Sejahtera Sempurna)

5. MKF (Manik Kembar Farm)

6. TPC (Tri Putra Cerdas)

7. MMF (Makmur Mulyo Family)

8. H. Mukhlis

9. GK Farm Cibinong

10. New Hope

11. MMS
Peternak yang melakukan sistem beternak secara mandiri berjumlah 6 orang peternak, keunggulan dari sistem ini adalah keuntungan bisa lebih maksimal dibandingkan karena harga sapronak bisa lebih murah, peternak bebas memilih jenis sapronak yang diinginkan seperti DOC, merk pakan yang sesuai kebutuhan, selain itu harga jual dapat lebih tinggi karena biaya pemasaran yang rendah, kekurangannya tidak adanya jaminan pasar dan harga apabila harga ayam turun.

\section{Persepsi Peternak Ayam Broiler terhadap kemitraan}

\section{Persepsi Peternak Mandiri terhadap Kemitraan}

Persepsi peternak mandiri terhadap kemitraan berada pada kategori cukup dengan rataan skor 61,5. Persepsi ini menurut peternak mandiri menganggap prosedur bermitra yang harus dipenuhi oleh peternak sebelum melakukan kemitraan cukup sulit karena adanya anggunan seperti sertifikat tanah, BPKB motor atau mobil.

\section{Persepsi Peternak Mandiri terhadap Prosedur Bermitra}

Persepsi peternak mandiri terhadap prosedur bermitra yaitu ada dua indikator atribut yaitu persyaratan bermitra dan pemberian modal/kredit. Persepsi peternak mandiri terhadap prosedur bermitra berada pada kategori kurang baik dengan rataan skor 12.83 .

\section{Persepsi Peternak Mandiri terhadap Pelayanan Teknis Budidaya}

sebanyak 4Porang si peternak mandiri terhadap sebanexakyantaprangnis berada pada kategori baik dengan ratan skor sebesar 19,8. Peternak sebaniak 2urgrang pelayanan teknis yang sebangyekk arprang rirang baik, dalam proses sebanviflua da orapgak selalu berjalan sesuai sebanyak an qrang terkadang terdapat kendala di

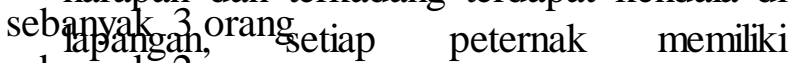
sebanyati norang masing-masing respon sebanfak kaporangluhan ini dilakukan oleh sebanyak kendala yang dimaksud diatas 


\section{Persepsi Peternak Mandiri terhadap Pelayanan Sarana Produksi}

Persepsi peternak terhadap pelayanan sarana produksi berada pada kategori baik dengan rataan skor 22. Hal ini menunjukkan persepsi peternak mandiri terhadap pelayanan sarana produksi menganggap kurang baik dikarenakan banyaknya peternak yang mengeluh akibat kualitas pakan dan harga yang tinggi.

\section{Persepsi Petemak Mandiri terhadap Pelayanan Pasca Panen}

pelayanan pascapanen berada pada kategori cukup dan memiliki rataan skor sebesar 6,8, hal ini perlu diperhatikan oleh perusahaan agar para peternak mandiri mau bergabung dengan perusahaan.

\section{Persepsi Peternak Mitra terhadap Kemitraan}

Persepsi peternak mitra terhadap kemitraan berada pada kategori cukup dengan rataan skor 69,48 . Peternak mitra menganggap banyaknya ketidaksesuaian dengan kesepakatan yang telah dibuat seperti kualitas DOC dan kualitas pakan. Selain itu peternak juga berharap harga jual yang ditetapkan perusahaan dinaikkan dari sebelumnya.

\section{Persepsi Peternak Mitra terhadap Prosedur Bermitra}

persepsi peternak ayam broiler tentang prosedur bermitra memiliki rataan skor sebesar 16,6 atau berada pada kategori cukup, Persyaratan bermitra merupakan serangkaian kegiatan atau syarat yang harus dipenuhi oleh peternak sebelum menjalin kemitraan dengan perusahaan ternak. Persyaratanpersyaratan tersebut yaitu menunjukkan adanya lahan, kandang ayam, lingkungan peternakan dan yang terpenting yaitu peternak harus menunjukkan surat/akta tanah kepada pihak perusahaan sebagai jaminan untuk perusahaan.

\section{Persepsi Peternak Mitra terhadap Pelayanan Teknis Budidaya \\ Persepsi peternak tentang pelayanan teknis berada dalam kategori}

baik. Hal ini ditunjukkan dengan rataan skor 21. Artinya pelayanan teknis yang diberikan perusahaan kepada peternak mitra baik namun peternak masih membutuhkan bimbingan dalam hal teknis dari pihak perusahaan dan dilakukan secara teratur setiap masa periode.

Bimbingan merupakan hal yang sangat dibutuhkan oleh peternak walaupun mereka menganggap sudah cukup baik, sebanyak 19 orang $(57,6 \%)$ peternak adalah peternak pemula sehingga tidak pernah mempelajari ilmu-ilmu beternak sebelumnya. Tetapi dapat dilakukan sesuai permintaan peternak. Metodenya adalah mengecek kinerja anak kandang, memberikan penyuluhan langsung atas penggunaan pakan, obat, dan vaksin

\section{Persepsi Peternak Mitra terhadap Pelayanan Sarana Produksi}

Persepsi peternak tentang pelayanan sarana produksi secara umum berada dalam kategori baik. Hal ini ditunjukkan dengan rataan skor 24,4. Pelayanan sarana produksi yang diberikan perusahaan seperti penerapan harga kontrak DOC, kualitas DOC, harga kontrak pakan, kualitas pakan, harga dan kualitas obat dan vaksin serta jadwal pengiriman sarana produksi sudah cukup baik.

Indikator pelayanan sarana produksi dengan atribut harga DOC dengan skor 78. Harga DOC yang ditetapkan perusahaan terjangkau dan tidak melebihi harga pasar. Ini merupakan salah satu alasan mengapa peternak masih tetap memilih untuk bergabung dengan kemitraan karena peternak bisa mendapatkan DOC dengan harga kontrak yang sudah ditentukan dan terjangkau. Selain itu juga alasan kenapa bermitra dengan perusahaan, karena harga DOC dan pakan yang mahal. Namun harga kontrak DOC ini dapat berubah ketika terjadi perubahan harga pasar. Peternak mitra berharap walaupun terjadi perubahan harga peternak masih bisa mendapatkan DOC dengan harga yang lebih murah dan tidak melebihi harga pasar. 
Persepsi Peternak Mitra terhadap Pelayanan Pascapanen

Pelayanan pascapanen memiliki rataan skor sebesar 7,5 dan berada pada kategori cukup. Hasil ini menunjukkan peternak di Kecamatan Leuwiliang Kabupaten Bogor memberikan persepsi mereka dengan cukup terhadap indikator kemitraan pelayanan pascapanen. Hal ini tidak terlepas dari faktor ekonomi seperti atribut kesesuaian harga output dan kecepatan pembayaran hasil panen. Atribut-atribut ini merupakan atribut yang dianggap peternak mitra harus diperhatikan dan keberadaan dari atributatribut ini sangat penting.

Faktor-faktor yang mempengaruhi persepsi peternak ayam broiler terhadap kemitraan

Hubungan umur peternak dengan persepsi terhadap pelaksanaan kemitraan

Berdasarkan uji rank spearman diketahui nilai signifikansi sebesar 0.381 , karena nilai signifikansi > 0,2 maka dapat diartikan tidak berkorelasi antara umur responden dengan persepsi peternak terhadap kemitraan di Kecamatan Leuwiliang Kabupaten Bogor. Untuk tingkat koefisien korelasi diperoleh angka koefisien korelasi sebesar 0,158 artinya tingkat hubungan antara umur responden dengan persepsi peternak terhadap kemitraan di Kecamatan Leuwiliang Kabupaten Bogor memiliki tingkat kekuatan korelasi lemah.

\section{Hubungan pengalaman beternak dengan persepsi petemak terhadap pelaksanaan kemitraan}

Berdasarkan uji rank spearman diketahui nilai signifikansi sebesar 0,114 , karena nilai signifikansi > 0,2 maka dapat diartikan berkorelasi antara pengalaman beternak dengan persepsi peternak terhadap kemitraan di Kecamatan Leuwiliang Kabupaten Bogor. Untuk tingkat koefisien korelasi diperoleh angka koefisien korelasi sebesar $-0,280$ artinya tingkat hubungan antara pengalaman beternak dengan persepsi peternak terhadap kemitraan di Kecamatan Leuwiliang Kabupaten Bogor memiliki tingkat kekuatan korelasi lemah.

Hubungan jumlah tanggungan keluarga peternak dengan persepsi peternak terhadap pelaksanaan kemitraan

Berdasarkan uji rank spearman menunjukkan nilai signifikansi sebesar 0,709 , karena nilai signifikansi $>0,2$ $(0,709>0,2)$ maka dapat diartikan tidak berkorelasi antara jumlah tanggungan keluarga dengan persepsi peternak terhadap kemitraan di Kecamatan Leuwiliang Kabupaten Bogor. Untuk tingkat koefisien korelasi diperoleh angka koefisien korelasi sebesar 0,068 artinya tingkat hubungan antara jumlah tanggung keluarga dengan persepsi peternak terhadap kemitraan memiliki tingkat kekuatan korelasi lemah.

Angka koefisien korelasi yang didapat bersifat positif. Dengan demikian dapat diartikan semakin banyak tanggungan keluarga maka persepsi terhadap atribut kemitraan semakin baik yaitu peternak memberikan persepsi tentang pelaksanaan kemitraan.

\section{Hubungan pendapatan peternak dengan persepsi peternak terhadap pelaksanaan kemitraan}

Berdasarkan uji rank spearman diketahui nilai signifikansi sebesar sebesar 0,625 , karena nilai signifikansi $>0,2$ $(0,625>0.2)$ maka dapat diartikan tidak berkorelasi antara pendapatan peternak dengan persepsi peternak terhadap kemitraan di Kecamatan Leuwiliang Kabupaten Bogor. Untuk tingkat koefisien korelasi diperoleh angka koefisien korelasi sebesar 0,088 artinya tingkat hubungan antara pendapatan peternak dengan persepsi peternak terhadap kemitraan di Kecamatan Leuwiliang Kabupaten Bogor memiliki tingkat kekuatan korelasi lemah. 


\section{Hubungan jumlah ternak dengan persepsi peternak terhadap pelaksanaan kemitraan}

Berdasarkan uji rank spearman didapat sebesar 0,015 , karena nilai signifikansi $<0,2(0,015<0.2)$ maka dapat diartikan berkorelasi antara jumlah ternak dengan persepsi peternak terhadap kemitraan di Kecamatan Leuwiliang Kabupaten Bogor.

Untuk tingkat koefisien korelasi diperoleh angka koefisien korelasi sebesar -0.419 artinya tingkat hubungan antara jumlah ternak dengan persepsi peternak terhadap kemitraan di Kecamatan Leuwiliang Kabupaten Bogor memiliki tingkat kekuatan korelasi lemah.

Angka koefisien korelasi yang didapat bersifat negatif yaitu sebesar 0,419 sehingga hubungannya tidak searah. Dengan demikian dapat diartikan semakin rendah jumlah ternak, maka semakin baik persepsi yang diberikan oleh peternak. Jumlah ternak yang dimiliki peternak di Kecamatan Leuwiliang Kabupaten Bogor memiliki jumlah ternak yang rendah/sedik it $(72,7 \%$ peternak).

\section{KESIMPULAN DAN IMPLIKASI KEBIJAKAN}

Kesimpulan

1. Karakteristik peternak sebagian besar peternak berumur kategori muda antara 23-44 tahun, sebanyak $(69,7 \%)$, berjenis kelamin laki-laki, memiliki pengalaman beternak kategori pemula $(57,6 \%)$ lebih dari setengah peternak $(72,7 \%)$ memiliki ternak pada kategori sedikit, lebih dari sebagian peternak memiliki tanggungan keluarga sedikit $(60,6 \%)$ dan sebagian besar $(48,5 \%)$ peternak berpendapatan antara 1.000.000-3.500.000 dalam usaha ternaknya.

2. Pola kemitraan yang ada di Kecamatan Leuwiliang ada 2 diantaranya Pola Inti Plasma dan Kerjasama Operasional. Keragaan kemitraan Peternak ayam broiler di Kecamatan Leuwiliang Kabupaten Bogor didapatkan bahwa mayoritas status peternak yaitu bermitra. Data keragaan kemitraan peternak ayam broiler Kecamatan Leuwiliang Kabupaten Bogor yaitu BNF (Berkah Nyawiji Farm), TJB (Taman Jasmin Bogor), PT. BBM (Berkah Broiler Mandiri), SMSS (Satwa Maju Sejahtera Sempurna), MKF (Manik Kembar Farm), TPC (Tri Putra Cerdas), MMF (Makmur Mulyo Family), H. Mukhlis, GK Farm Cibinong, New Hope, MMS dan Mandiri .

3. Peternak mandiri memberikan persepsi dengan kurang baik terhadap kemitraan dengan nilai rataan skor keseluruhan sebesar 14,76. Peternak Mitra di Kecamatan Leuwiliang Kabupaten Bogor secara umum memberikan persepsi sebesar 75,04. Atau berada pada kategori baik terhadap atributatribut kemitraan secara keseluruhan.

4. Faktor-faktor yang mempengaruhi persepsi peternak ayam broiler terhadap kemitraan di kecamatan Leuwiliang Kabupaten Bogor yaitu jumlah ternak dengan nilai nilai signifikansi sebesar 0,015 , karena nilai signifikansi $<0,2 \quad(0.015<0,2)$, dan pengalaman ternak dengan nilai signifikansi sebesar 0,114 , karena nilai signifikansi $<0,2(0,114<0,2)$

\section{Implikasi Kebijakan}

1. Bagi Perusahaan, hendaknya perusahaan memberikan kualitas pakan dan DOC yang baik.

2. Bagi Peternak sebaiknya melakukan seleksi penerimaan sapronak, sehingga kegiatan budidaya ayam broiler yang berlangsung akan lebih baik.

3. Bagi Pemerintah agar dapat memperhatikan keluhan terutama masalah harga jual di Peternak.

\section{Daftar Pustaka}

Badan Pusat Statistik. 2017. Peternakan Dalam Angka. Diakses tanggal 5 Agustus 2018. www.bps.go.id 
Pramita, D.A, Kusnadi Nunung, Harianto. 2017. Efisiensi Teknik Usaha Ternak Ayam Broiler Pola Kemitraan di Kabupaten Limapuluh Kota. [Skripsi]. Fakultas Ekonomi dan Manajemen. Institut Pertanian Bogor.

Purbata, A.G, Cepriadi, Kausar. 2015. Motivasi Peternak Plasma Ayam Broiler Dalam Bermitra di Kecamatan Kampar Kiri Tengah
Kabupaten Kampar. Jurnal Online Mahasiswa Vol 2 No. 2.

Rohim, S. 2017. Analisis Faktor-Faktor Yang Mempengaruhi Permintaan Daging Ayam Broiler di Pasar Tradisional Kecamatan Citeureup Kabupaten Bogor. [Skripsi]. Fakultas Ekonomi dan Manajemen. Institut Pertanian Bogor.

Sugiyono. 2016. Metode Penelitian Bisnis. Alfabeta, Bandung. 
Lampiran 1 Persepsi Peternak Mandiri Terhadap Kemitraan

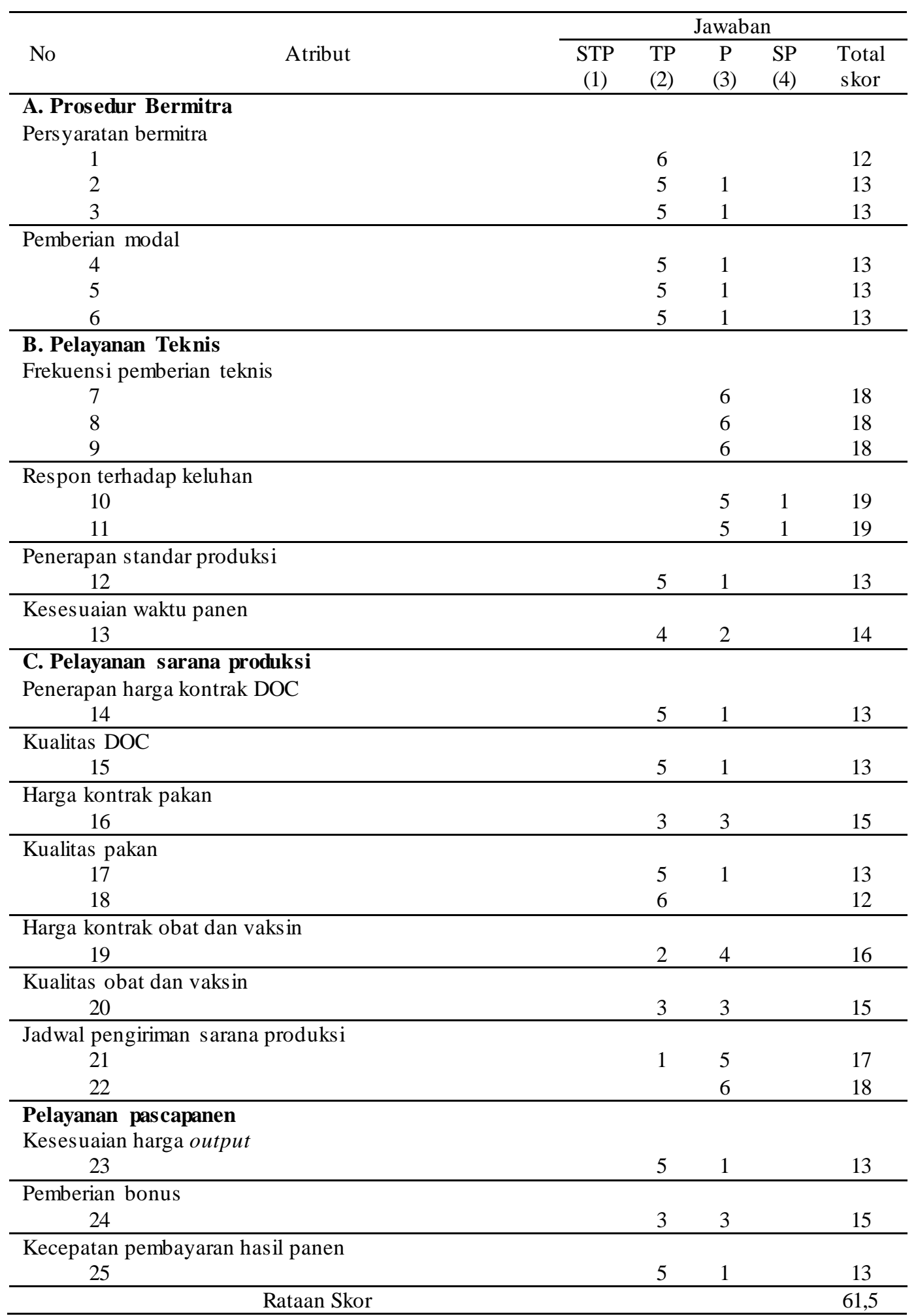

Sumber: Data Primer yang diolah, 2018

Keterangan :

Kurang Baik $=25-50$

Cukup $\quad=51-76$

Baik $\quad=>76$

Keterangan: $\quad$ STP = Sangat Tidak Puas

$\mathrm{TP}=$ Tidak Puas

$\mathrm{P} \quad=$ Puas

SP $=$ Sangat Puas 
Lampiran 2 Persepsi Peternak Mitra Terhadap Kemitraan

\begin{tabular}{|c|c|c|c|c|c|c|}
\hline \multirow[b]{2}{*}{ No } & \multirow[b]{2}{*}{ Atribut } & \multicolumn{5}{|c|}{ Jawaban } \\
\hline & & $\begin{array}{c}\text { STP } \\
(1)\end{array}$ & $\begin{array}{l}\text { TP } \\
\text { (2) }\end{array}$ & $\begin{array}{c}\mathrm{P} \\
(3)\end{array}$ & $\begin{array}{l}\text { SP } \\
\text { (4) }\end{array}$ & $\begin{array}{l}\text { Total } \\
\text { skor }\end{array}$ \\
\hline \multicolumn{7}{|c|}{ A. Prosedur Bermitra } \\
\hline \multicolumn{7}{|c|}{ Pers yaratan bermitra } \\
\hline 1 & & & 4 & 22 & 1 & 78 \\
\hline 2 & & & 1 & 26 & & 80 \\
\hline 3 & & & & 25 & 2 & 83 \\
\hline \multicolumn{7}{|c|}{ Pemberian modal } \\
\hline 4 & & & 14 & 13 & & 67 \\
\hline 5 & & & 13 & 14 & & 68 \\
\hline 6 & & & 13 & 14 & & 68 \\
\hline \multicolumn{7}{|c|}{ B. Pelayanan Teknis } \\
\hline \multicolumn{7}{|c|}{ Frekuensi pemberian teknis } \\
\hline 7 & & & 4 & 18 & 5 & 82 \\
\hline 8 & & & & 20 & 7 & 88 \\
\hline 9 & & & & 18 & 9 & 90 \\
\hline \multicolumn{7}{|c|}{ Respon terhadap keluhan } \\
\hline 10 & & & 10 & 10 & 7 & 78 \\
\hline 11 & & & 10 & 10 & 7 & 78 \\
\hline \multicolumn{7}{|c|}{ Penerapan standar produksi } \\
\hline 12 & & & 6 & 21 & & 75 \\
\hline \multicolumn{7}{|c|}{ Kesesuaian waktu panen } \\
\hline 13 & & & 5 & 22 & & 76 \\
\hline \multicolumn{7}{|c|}{ C. Pelayanan sarana produksi } \\
\hline \multicolumn{7}{|c|}{ Penerapan harga kontrak DOC } \\
\hline 14 & & & 4 & 22 & 1 & 78 \\
\hline \multicolumn{7}{|l|}{ Kualitas DOC } \\
\hline 15 & & & 18 & 9 & & 63 \\
\hline \multicolumn{7}{|c|}{ Harga kontrak pakan } \\
\hline 16 & & & 7 & 20 & & 74 \\
\hline \multicolumn{7}{|c|}{ Kualitas pakan } \\
\hline 17 & & & 17 & 10 & & 64 \\
\hline 18 & & 1 & 18 & 8 & & 61 \\
\hline \multicolumn{7}{|c|}{ Harga kontrak obat dan vaks in } \\
\hline 19 & & & 3 & 24 & & 78 \\
\hline \multicolumn{7}{|c|}{ Kualitas obat dan vaksin } \\
\hline 20 & & & 2 & 25 & & 79 \\
\hline Jadwal pengi & an sarana produksi & & & & & \\
\hline 21 & & & & 26 & 1 & 82 \\
\hline 22 & & & & 27 & & 81 \\
\hline Pelayanan $p$ & apanen & & & & & \\
\hline $\begin{array}{c}\text { Kesesuaian h } \\
23\end{array}$ & a output & & 12 & 14 & & 68 \\
\hline Pemberian bo & & & & & & \\
\hline 24 & & 1 & 4 & 21 & 1 & 76 \\
\hline Kecepatan pe & ayaran hasil panen & & & & & \\
\hline 25 & & & 21 & 5 & 1 & 61 \\
\hline & Rataan Skor & & & & & 69,48 \\
\hline $\begin{array}{l}\text { Sumber: Dat: } \\
\text { Keteranoan. }\end{array}$ & rimer yang diolah, 2018 & & & & & \\
\hline $\begin{array}{l}\text { Keterangan : } \\
\text { Kurang Baik }\end{array}$ & $=25-50$ & & & & & \\
\hline Cukup & $=51-76$ & & & & & \\
\hline Baik & $=>76$ & & & & & \\
\hline Keterangan: & STP $=$ Sangat Tidak Puas & & & & & \\
\hline & $=$ Sangat Puas & & & & & \\
\hline & $=$ Puas & & & & & \\
\hline & $=$ Tidak Puas & & & & & \\
\hline
\end{tabular}


Lampiran 3. Korelasi Karakteristik Peternak dengan Persepsi Peternak terhadap Kemitraan di Kecamatan Leuwiliang Kabupaten Bogor

\begin{tabular}{|c|c|c|c|c|c|c|}
\hline \multirow[b]{2}{*}{ Karakteristik } & \multirow[b]{2}{*}{$\begin{array}{c}\text { Uji } \\
\text { Korelasi } \\
\text { Rs }\end{array}$} & \multicolumn{5}{|c|}{ Persepsi tentang } \\
\hline & & $\begin{array}{c}\text { Prosedur } \\
\text { Penerimaan } \\
\text { mitra }\end{array}$ & $\begin{array}{l}\text { Pelayanan } \\
\text { teknis }\end{array}$ & $\begin{array}{c}\text { Pelayanan } \\
\text { sarana } \\
\text { produksi }\end{array}$ & $\begin{array}{c}\text { Pelayanan } \\
\text { pasca } \\
\text { panen }\end{array}$ & $\begin{array}{l}\text { Persepsi } \\
\text { Kemitraan }\end{array}$ \\
\hline \multirow{2}{*}{ Umur } & Koefisien & 0,094 & $-0,046$ & $-0,078$ & $-0,135$ & 0,158 \\
\hline & Sig & 0,604 & 0,799 & 0,668 & 0,454 & 0,381 \\
\hline \multirow{2}{*}{$\begin{array}{c}\text { Pengalaman } \\
\text { Beternak }\end{array}$} & Koefisien & 0,114 & $-0,036$ & $-0,056$ & $-0,188$ & $-0,280 * *$ \\
\hline & Sig & 0,526 & 0,841 & 0,757 & 0,296 & 0,114 \\
\hline \multirow{2}{*}{$\begin{array}{c}\text { Tanggungan } \\
\text { Keluarga }\end{array}$} & Koefisien & 0,115 & $-0,035$ & $0,351 *$ & 0,212 & 0,068 \\
\hline & Sig & 0,525 & 0,848 & 0,045 & 0,237 & 0,709 \\
\hline \multirow[t]{2}{*}{ Pendapatan } & Koefisien & 0,086 & $0,276^{* *}$ & $-0,355^{*}$ & $-0,049$ & 0,088 \\
\hline & Sig & 0,633 & 0,120 & 0,043 & 0,786 & 0,625 \\
\hline \multirow{2}{*}{$\begin{array}{l}\text { Jumlah } \\
\text { Ternak }\end{array}$} & Koefisien & $-0,295^{*}$ & $-0,026$ & $-0,002$ & $-0,258^{* *}$ & $-0,419 *$ \\
\hline & Sig & 0,095 & 0,884 & 0,990 & 0,147 & 0,015 \\
\hline \multirow[t]{3}{*}{ Keterangan: } & \multicolumn{3}{|c|}{$=$ Sig $\mathrm{p}<0,2=$ berkorelasi } & \multicolumn{2}{|c|}{$\mathrm{r}_{\mathrm{s}}=$ rank spearman } & \\
\hline & \multirow{2}{*}{\multicolumn{3}{|c|}{$=$ Sig $\mathrm{p}>0,2=$ tidak berkorelasi }} & \multicolumn{2}{|c|}{$* \operatorname{sig} \mathrm{p}<0,1$} & \\
\hline & & & & $*$ & 0,2 & \\
\hline
\end{tabular}

Tingkat keakuratan sebesar $80 \%$ pada sign $\mathrm{p}<0,2$.

Koefisien Korelasi/Tingkat Kekuatan

$0 \leq \mathrm{rs} \leq 0,35=$ Lemah

$0,35<\mathrm{rs} \leq 0,7 \quad=$ Sedang

$0,7<\mathrm{rs} \leq 0,1 \quad=$ Kuat 